\title{
PERIODIZATION OF DEVELOPMENT OF ETHNIC RELATIONS OF WESTERN UKRAINE AND POLAND (1918-1939)
}

\author{
Lilia Pylypenko \\ Department of History and Political Sciences \\ National University of Life and Environmental Sciences of Ukraine \\ 15 Heroiv Oborony str., Kyiv, Ukraine, 03041 \\ lilichka-p@yandex.ru \\ Serhii Bilan \\ Department of History and Political Sciences \\ National University of Life and Environmental Sciences of Ukraine \\ 15 Heroiv Oborony str., Kyiv, Ukraine, 03041 \\ bilanso@bigmir.net
}

\begin{abstract}
The article makes an attempt to investigate the peculiarities and determine the regularities of cooperation between the Ukrainian and Polish states during the time of the Second Rzeczpospolita, to recreate the overall picture of events and their subsequent influence on the relations between the two countries. Analysis of the concepts of activities of various representatives of the Polish government is presented, which helps to prove that Poland's constant struggle for spheres of influence in the international arena led to unpleasant consequences that claimed the lives of the representatives of many nations, including Ukrainians and Poles. At the same time, the struggle of the Polish national chauvinists and the Ukrainian patriotic forces did not allow Ukrainians to defend the sovereignty of its state, since the military-political situation in the region, the position of the Entente countries, as well as the ethnic relations of the region did not contribute to this. The attempt to normalize the Ukrainian-Polish relations in the Second Commonwealth did not bring the expected results because it was not seen by the government as a positive solution to the problem. Having negatively impacted the life of Ukrainians, these actions were remembered as the last wasted attempt to improve the situation on the eve of the Second World War. Ukrainians in such a difficult situation were forced to adjust to the requirements of time, and therefore quite often changed the vector of activity toward the cultural and social direction. The intellectuals were fighting for the right to teach in Ukrainian in schools, preserving traditions and gaining minor rights and privileges. The positions of the Polish government, in this case, remained unchanged, with the exception of the insignificant tolerant statements of its individual representatives. Consequently, Polish politics did not achieve the desired results.
\end{abstract}

Keywords: Ukraine, Poland, sanation, pacification, UNDO, international relations, Eastern Galicia, assimilation, polonization.

\section{Introduction}

The global transformation of all countries of the world to a new qualitative state and the type of civilization of the third millennium requires the gradual but steady integration of Ukraine into the system of international relations and world integration processes.

In the future, for Ukraine, its integration into Europe will be of great importance, because at the present stage our country enters the Western European socio-economic space with a broad front.

Poland is the most consistent and effective partner of Ukraine in its European integration aspirations among the post-socialist countries that are members of the European Union and have common borders, cultural and historical traditions with our country, as well as close geo-economic interests.

The last ten years in comparison with the centuries-old past of our nations have become the exclusive page of joint history, since the idea of good-neighborliness has become the main value that promotes the formation and development of contacts between our states during this period. The links between peoples in the political, economic and spiritual life of Ukraine and Poland have long historical traditions, but they have not always evolved in an atmosphere of peaceful coexistence and cooperation. In the common history of the two countries there are many "stumbling blocks", the interpretation and evaluation of which greatly affects the process of building and deepening bilateral relations. In particular, one of such periods of controversial events between 
the Ukrainian and Polish peoples was a difficult time between world wars, including the time of the Second Commonwealth. The constant struggle for spheres of influence, attempts to seize more space for the resettlement of their people, on the very front of Poland, which actively populated the Ukrainian lands with Poles, led to the disastrous consequences that took away the lives of many Poles and Ukrainians.

The first attempts to give an overall assessment of Ukrainian-Polish relations during 19181939 were carried out by their contemporaries, who, in the early 1930's, made the first steps in the process of consolidating Polish society and affirming the idea of the importance of strengthening friendly relations with other states, as well as the rise of the role of the Second Commonwealth in the structure of the international relations of Eastern and Central Europe. In particular, a striking example of this concept was presented in [1], which contains important information about the political parties that existed at that time in the Polish parliament.

Research presented in [2] has been recognized worldwide, which enabled to discover and make public the early works of Polish authors, to restore the masterpieces of the national Polish and Ukrainian culture. The researcher gave a new, objective and comprehensive interpretation of the history of Polish culture, showed its connections with the culture of other peoples. The actual result of the great scientific work was the fundamental monograph "The History of Polish Culture", in which the author convincingly proved that the Polish Commonwealth made a significant contribution to the further scientific development of Europe.

During the 1940s and 1990s in Poland, as in Ukraine, the problem of interethnic relations was hardly covered as it was the subject of silence, ideological speculation or mere falsifications. Scientists only partially touched the issues related to the activities of the OUN and the CPWU (Communist Party of Western Ukraine).

In modern Ukraine and Poland, scholars, having the opportunity to freely study the historical issues of the relations between the Polish and Ukrainian peoples, have focused on the interaction of Ukraine and Poland in the international arena. Among the large number of modern works it is necessary to mention the research presented in [3], which, on the basis of the wide use of factual material, made an attempt to comprehensively analyze the relations between Ukrainians and Poles in the interwar years. A fundamental work remains published in [4] became the first in the Ukrainian modern historiography, the synthesis of the history of Poland, made on the basis of a deep elaboration of a large number of sources and interpretative achievements of foreign scientific literature. Also interesting was the new two-volume edition of "Poland and Ukraine in the thirties and forties of the XX century. Unknown documents from archives of special services" [5, 6]. The situation of the Ukrainian minority in Poland was studied in [7, 8].The publication of documents and the publication of monographic works by Ukrainian historians $[9,10]$ greatly contributed to a better understanding of the factors shaping the Polish-Ukrainian relations. The culture of interethnic communication in Ukraine was analyzed in detail in [11] by the author as a scientist and as a representative of the Ukrainian government

The Institute of Ukrainian Studies of the National Academy of Sciences of Ukraine named after I. Krypyakevich, the Institute of History of Ukraine of the National Academy of Sciences of Ukraine, the Institute for Political and Ethnic Studies of the National Academy of Sciences of Ukraine, as well as other scientific centers of our country are actively working on the study of complex Ukrainian-Polish relations. Due to this research, in modern Ukrainian historiography, the historical truth about the everyday life of Ukrainians in Poland, Poles in Ukraine during the XX century, the rehabilitation of a number of prominent figures repressed by the Soviet totalitarian regime was found, becoming the basis for further resolving difficult issues and mutual claims in relations two states.

Of particular interest are Ukrainian-Polish ties in the years before the Second World War. Among the works devoted to this problem is the thorough monograph [12], in which a lot of documents were used and the Ukrainian-Polish relations in Eastern Galicia were analyzed objectively in the context of Polish national politics in the first five years after the end of the First World War. The researcher analyzed in detail the programs of Ukrainian parties and leading Ukrainian organizations on the national issue and their attitude to the Polish state, and also highlighted the main 
aspects of Polish politics regarding the Ukrainian issue and the activities of major political parties and political groups through the prism of Polish-Ukrainian relations [13].

Despite the fact that the named works of both Ukrainian and Polish scholars are characterized by fragmentation and one-sidedness in coverage of the activities of Polish and Ukrainian organizations, their work became the foundation for further historical research.

\section{Aim of research}

The aim of the article is to analyze and distinguish periods in the policy of Polish governments in the national question in the territory of Western Ukraine on the basis of streamlining information about public and political processes in Ukraine and Poland, which resulted in active political actions of Ukrainian and Polish organizations and the emergence of a conflict between them, policy change of Polish government regarding the Ukrainian minority during 1918-1939.

\section{Results}

The dominant type of interethnic relations in the territory of Western Ukraine in the 20-30's of the twentieth century were the relations between the Ukrainians, who constituted the overwhelming majority of the local population, and the ethnic Poles, whom the state supported, and which provided the dominant position of Polish culture in Volyn and in Eastern Galicia. In relation to ethnic Ukrainians among Poles, the views dominated by the influence of the Polish national democrats prevailed, and therefore the peoples of Poland, which were subject to the political and cultural influence of Poles and their states, were also related to the Polish nation [3]. At the heart of this relationship was the statement about the cultural and civilizational backwardness of these peoples, as they did not reach the level of a "political nation," and therefore subject to assimilation. Such a policy provided for a change in the national structure of the population of Eastern Galicia and Volyn. The policy of national assimilation through linguistic, educational and confessional policies envisaged the rapid polonization of Ukrainians, and the nature of interethnic relations can be defined by the intensification of the Polish-Ukrainian confrontation.

The economic policy of the Polish government on the Ukrainian lands also pursued the objective of inhibiting the development of these lands and turning them into an agrarian and raw material appendage for the Polish lands. The government officially divided Poland into two economic territories: Poland "A", that is, the indigenous Polish lands, and Poland "B", which consisted of captured Ukrainian and Belarusian lands. Thanks to cheap loans and public procurement, the industrial development of the "A" sector was stimulated, while on the Ukrainian territory there was a limitation on the granting of loans to industrial enterprises [5, p. 3].

The colonial policy promoted by the Polish government and the growing trend of the gradual economic downturn in Western Ukraine have become more and more a feature of economic catastrophe: about $25 \%$ of the territory and $28 \%$ of the population of the state accounted for Lviv, Stanislavsk, Ternopil and Volyn provinces, but only $16.6 \%$ of industrial enterprises and less $10 \%$ of workers.

Such artificial restraint of the economic and industrial development of Western Ukraine did not allow the liberation of a large number of able-bodied populations from the agricultural sector to work in factories, and thus mitigate the problems of the village, which was aggravated by agrarian overpopulation and the gradual landlessness of the peasants. The situation in agriculture on the Ukrainian lands was complicated by the fact that the Polish government in this region transferred the best land withdrawn as a result of the forced parceling of estates to the disposal of Polish sedentary who, in their turn, should promote the assimilation of the Ukrainian population and carry out punitive functions, if needed. In 1919-1929 about 80 thousand settlers received on Ukrainian lands about 600 thousand hectares of land [9, p. 51].

Polish government circles tried to oust the concept of "Ukrainian". The Ukrainian population was officially called "Rusyns", and the territory of Western Ukraine was called "Eastern Little Poland". The beginning of the active polonization of these lands became the law of July 31, 1924, which proclaimed only Polish as the state language throughout Poland. The official Warsaw has taken the course to the complete elimination of the Ukrainian school. 
Polish politics until 1923 focused on the need for the legal recognition of the Entente of real Eastern borders and control of Poland over Eastern Galicia. The main idea of the socio-political life of Ukrainians in Galicia in 1919-1926 was the opposition to the Polish occupation regime, the movement for the restoration of Ukrainian statehood, and the opposition to the assimilation policy of the official authority of the Second Polish Commonwealth.

A new stage in the policy affecting Ukrainians began immediately after the May coup in Poland and the establishment of the so-called sanation regime, the core of which was formed by Y. Pilsudsky's ideological comrades in 1926 . When they came to power, they sought to "rehabilitate" the political climate and economic the situation in the state, which envisaged mitigation of relations in the field of national policy. The adherents of Y. Pilsudsky at such a critical moment could not fail to take into account the interests of the Ukrainian population that lived compactly in strategically important Southeastern regions of the state and formed the majority in these lands [10, p. 74].

Considering the Ukrainian issue as a purely internal Polish problem, they proposed a program of state assimilation as a guarantee of preserving their own nationality in minorities in order to form a conscious sense of belonging to statehood, which in the first place envisaged the education of loyal citizens of the state through methods of political, economic and cultural character.

From May 15, 1926, to March 17, 1930, when the Polish government 5 times headed the representative of the liberal wing of the rehabilitation of $\mathrm{K}$. Bartel, the policy principles were formed in the national question, but the ways and methods for their implementation were not specified. At this time, the Ukrainian problem was mainly solved at the level of local authorities of voivodships.

A new wave of exacerbation of the situation took place in the early 1930's, due to the global economic crisis that began in 1929. From the Polish side, calls for a frontal offensive against all Ukrainian citizens began, and radical nationalist forces began to demand that the government take decisive measures in Ukrainian voivodships [3, p. 320]. In view of the explosion of the internal political situation, the so-called "pacification" of the Ukrainian peasants, was launched by the government.

Consequently, the events of 1930 showed the complete inability of the official ruling regime to resolve the Ukrainian issue. A vivid proof of this was the inconsistency in government actions, which was manifested in political attempts to resolve the problem, then in measures of a repressive nature. Under the pretext of fighting the sabotage of the Organization of the Ukrainian Nationalists, the army and police destroyed Ukrainian cultural and educational institutions, the beating of a civilian population took place, thousands of Ukrainians were brought to justice, including five deputies of the Sejm of the republic, which led to the disruption of the campaign against the Galician $[14$, p. 75$]$.

The application of power by the principle of collective responsibility exacerbated the Polish-Ukrainian relations. The transformation of the negative attitude of Ukrainians towards the Polish state was resolved through an understanding with the most influential Galician party - the Ukrainian National-Democratic Union (UNDU) [15, p. 218]. Already in early 1931, several secret meetings of Polish government officials with influential politicians of the UNDU took place, in particular with M. Galushchinsky, who at that time served as the chairman of the Ukrainian Parliamentary Representation. Negotiations, which were conducted by the head of the non-Party bloc of cooperation with the government T. Golubko and the deputy of the Sejm Y. Yenjeyevich from the Polish side, did not bring the expected results.

In general, between 1926 and 1935, in the relations between the two peoples, two political forces opposed each other: the negativism of the Polish regime and cooperation with it. In such circumstances, the possibility of understanding with the Ukrainian political camp, which is loyal to the authorities, is almost disappearing. At the same time, on the side of Polish political circles there was a "probing" of the policy of cooperation between UNDU and the intergovernmental Polish authorities that won in the 1930s.

Since 1938, the intensified propaganda among the Ukrainian-speaking Hutsuls, Lemkos and the inhabitants of the Carpathians began with the idea that they are separate peoples and not part of the Ukrainian nation. Attempts were being made to develop the Lemko dialect in a separate language, and Lemkos were inclined to move from Greek Catholicism to Orthodoxy in order to 
create a barrier between them and Galician Ukrainians. One of the varieties of this tactic was the efforts of the military to persuade the impoverished Ukrainian gentry, which was almost equal to the Ukrainian peasants, with the exception of its aristocratic titles, in that it is in no way similar to the peasantry [16, p. 185].

\section{Discussion}

The policy of Polish governments in the national question in the territory of Western Volyn can be divided into three periods:

1) 1921-1925 - characterized by the dominance of the doctrine of the Polish national-democratic forces, which meant only the Polish mono-cultural character of cultural life and the gradual assimilation of other peoples. Such policy was carried out by means of unification of the national boundaries. There was colonization in the form of military civilian sediment, the suppression of any manifestations of national liberation movements, administrative pressure in the political, cultural and religious spheres;

2) in 1926-1934, a change of the government's national policy is taking place; the government has declared the sanation regime, the official policy of assimilation of the national minorities in Poland. This program in the national question pursued the goal of replacing the policy of denationalization of national minorities by a federalist program of gradual state assimilation. This policy was meant to achieve, through certain actions, a loyal attitude of national minorities to the Polish state;

3) 1935-1939 in the policy of "sanation" there is a sharp turn to the right: a new concept was adopted - "the policy of strengthening the polishness of the Commonwealth", that is, the policy of coercive national-state assimilation of national minorities. The significant increase in the weight of the military in the social and political life of Poland, the propaganda of the Polish pilgrims' organizations by the national forms of Polish totalitarianism provoked the popularization of nationalist ideas, and activated radical concepts for resolving the Ukrainian national issue. This period was marked by an increase in polonization pressure in virtually all spheres of life of national minorities.

Thus, an attempt to normalize the Ukrainian-Polish relations in the Second Commonwealth did not bring the expected results because it was not seen by the government as a positive solution to the problem. Having a negative influence on the lives of Ukrainians, these actions were remembered as the last wasted attempt to improve the situation on the eve of the Second World War. Since the occupation of a part of the Ukrainian territories, political circles in Poland have been pursuing a policy aimed at polonizing the country's social life and gradually destroying Ukrainian education and culture for the ethnographic superiority of the Poles against Ukrainians.

The struggle of the Ukrainian patriotic forces and the Polish national chauvinists did not allow Ukrainians to defend the sovereignty of their state, as this was not supported by the military-political situation in the region, the position of the Entente countries, as well as ethnic relations in the region.

Taking advantage of the moment, Poland was able to achieve a positive result for itself at the International Council of Ambassadors that took place in 1923 and began to implement traditional methods of exploitation of the local population in the Ukrainian lands. On the surface, this political line was based on the standards and canons of international law, but in reality contributed to the assimilation of Ukrainians, their colonization and polonization. Despite these unfavorable conditions, the Ukrainian intellectuals fought against the invaders, employing a variety of political and military-terrorist methods. Part of political parties, having lost hope of possible liberation, has changed its political programs in the pro-Soviet way. In general, Ukrainian parties and organizations in the early 1920's did not represent a united force, there were constant contradictions and misunderstandings between them.

Ukrainians in such a difficult situation were forced to adapt to the requirements of time, and therefore quite often changed the vector of activity toward the cultural and social direction. The intellectuals were fighting for the right to teach in Ukrainian in schools, preserving traditions and gaining minor rights and privileges. The positions of the Polish government, in this case, remained unchanged, with the exception of minor tolerant statements of its individual representatives. 
In the national policy, the official definition was obtained by a program of state assimilation, which envisaged the transformation of Ukrainians into loyal citizens to the states. However, the Polish leadership did not develop a single concept for the implementation of this policy. Chauvinism, xenophobia and open hostility of Polish government structures sparked opposition from the local Ukrainian population, which managed to centralize all efforts, formed a kind of opposition to the colonial policy represented by UNDO representatives. The confrontation was unlikely for Ukrainians, therefore, the vector of patriotic struggle was shifted exclusively into the cultural and social direction, where there were still separate hopes of gaining certain privileges in education, culture, etc.

Consequently, Polish politics did not achieve the desired results. Through all its actions, the Ukrainian people showed that they can defend their own national state by their own national forces.

\section{Conclusions}

1. An attempt to normalize the Ukrainian-Polish relations in the Second Commonwealth did not bring the expected results, but instead had a negative influence on the lives of Ukrainians.

2. The military-political situation in the region, the position of the Entente countries, as well as ethnic relations in the region did not allow Ukrainians to defend the sovereignty of their state.

3. Taking advantage of the moment, Poland was able to achieve a positive result for itself at the International Council of Ambassadors that took place in 1923 and began to implement traditional methods of exploitation of the local population in the Ukrainian lands.

4. Ukrainians in such a difficult situation were forced to adapt to the requirements of time, and therefore quite often changed the vector of activity toward the cultural and social direction.

5. Through all their actions, the Ukrainian people showed that they can defend their own national state by their own national forces.

\section{References}

[1] Belcikowska, A. (1935). Partie polityczne i zwazki zawodowe w Polsce wobecwyborow do Sejmu i Senatu w 1935 r. Available at: https://fbc.pionier.net.pl/details/nn3qqlx

[2] Przeworskiego, Warszawa 1939 r. Vol. IV (1947). Krakow: Wydawnictwo F. Pieczatkowski, 124.

[3] Alekseevets, L. M. (2002). The Newest History of Poland (1918-1939). Kyiv: Aston, 320.

[4] Zashkilnyak, L. O., Krikun, M. G. (2002). History of Poland: From ancient times to the present day. Lviv: Lviv National Ivan Franko University, 752.

[5] Zashkilnyak, L. (2008). Ukraine and Poland in the XX century: from conflicts to understanding. Ukraine: cultural heritage, national consciousness, statehood. Lviv, 17, 3-18.

[6] Zashkilnyak, L. (1999). Methodology of history from antiquity to the present. Lviv, 133.

[7] Makar, Y., Gorny, M., Makar, V., Salyuk, A. (2011). From deportation to deportation. Social and political life of Holms-Podlaskie Ukrainians (1915-1947). Research. Memoirs. Documents. Vol. 1. Research. Chernivtsi: Bukrek, 731.

[8] Troshchinsky, V., Shevchenko, A. (1999). Ukrainians in the Worl. Kyiv: Alternatives, 351.

[9] Zastavnyy, F. D. (1993). Ukrainian Ethnic Land. Lviv: Svit, 176.

[10] Serhiychuk, V. (1997). Tragedy of Ukrainians in Poland. Ternopil, 439.

[11] Kuras, I. (1990). Routes of History. Kyiv: Politvydav Ukrayiny, 655.

[12] Krasivsky, O. (1998). Eastern Galicia and Poland in 1918-1923: Problems of Relationship. Kyiv, 299.

[13] Shynkarenko, T. (1999). Ukrainian national liberation movement in the years 1920-1923 in the context of foreign policy of the Western powers. Kyiv, 206.

[14] Zaitsev, O. (1994). Nationalism and national democracy: the origins of the conflict (1920-1930). Suchasnist, 2, 75-76.

[15] Gavrilov, B., Pylypiv, I. (1998). Attempts to "normalize" Ukrainian-Polish relations in the 1930 s. Ukrainian-Polish relations in 1918-1947. Warsaw, 218-229.

[16] Genyk, M. (1995). The Ukrainian Question in the Polish Policy of the Parliamentarian Period. Ukrainian Studies Studios, 1, 185-191. 